\title{
Apolipoprotein E Associated with Astrocytic Glia of the Central Nervous System and with Nonmyelinating Glia of the Peripheral Nervous System
}

\author{
Janet K. Boyles, Robert E. Pitas, Elizabeth Wilson, Robert W. Mahley, and John M. Taylor \\ Gladstone Foundation Laboratories for Cardiovascular Disease, Cardiovascular Research Institute, Departments of Pathology, Medicine, \\ and Physiology, University of California, San Francisco, California 94140-0608
}

\begin{abstract}
The plasma protein apolipoprotein (apo) $\mathbf{E}$ is an important determinant of lipid transport and metabolism in mammals. In the present study, immunocytochemistry has been used to identify apo $E$ in specific cells of the central and peripheral nervous systems of the rat. Light microscopic examination revealed that all astrocytes, including specialized astrocytic cells (Bergmann glia of the cerebellum, tanycytes of the third ventricle, pituicytes of the neurohypophysis, and Müller cells of the retina), possessed significant concentrations of apo $\mathrm{E}$. In all of the major subdivisions of the central nervous system, the perinuclear region of astrocytic cells, as well as their cell processes that end on basement membranes at either the pial surface or along blood vessels, were found to be rich in apo $E$. Extracellular apo $E$ was present along many of these same surfaces. The impression that apo $E$ is secreted by astrocytic cells was confirmed by electron microscopic immunocytochemical studies, which demonstrated the presence of apo $E$ in the Golgi apparatus. Apo $E$ was not present in neurons, oligodendroglia, microglia, ependymal cells, and choroidal cells. In the peripheral nervous system, apo $\mathbf{E}$ was present within the glia surrounding sensory and motor neurons; satellite cells of the dorsal root ganglia and superior cervical sympathetic ganglion as well as the enteric glia of the intestinal ganglia were reactive. Apo $\mathbf{E}$ was also present within the nonmyelinating Schwann cells but not within the myelinating Schwann cells of peripheral nerves. These results suggest that apo $E$ has an important, previously unsuspected role in the physiology of nervous tissue.
\end{abstract}

\section{Introduction}

Apolipoprotein (apo) $)^{1} \mathrm{E}$ is a well-characterized, $34,000-M_{\mathrm{r}}$, lipophilic protein that circulates in the plasma primarily as a constituent of specific lipoproteins (for review, see references 1 and 2 ). It is a key protein determinant responsible for the cellular recognition and internalization of chylomicron remnants, very

Address reprint requests to Dr. Boyles, Gladstone Foundation Laboratories, P.O. Box 40608, San Francisco, CA 94140-0608.

Received for publication 15 January 1985.

1. Abbreviations used in this paper: apo A-I, apo E, apolipoproteins AI and E; GFAP, glial fibrillary acidic protein.

J. Clin. Invest.

(c) The American Society for Clinical Investigation, Inc.

$0021-9738 / 85 / 10 / 1501 / 13 \quad \$ 1.00$

Volume 76, October 1985, 1501-1513 low density lipoproteins (VLDL), $\beta$-VLDL, and high density lipoproteins (HDL with apo $E)(1,2)$. Apo $E$ is recognized by two distinct cell surface receptors: the apo $B, E(L D L)$ receptor present on both hepatic and extrahepatic cells (3-6) and the apo $E$ receptor present on hepatic cells (4-6). One of the functions of apo $\mathrm{E}$ is to direct the receptor-mediated uptake of lipoproteins by the liver. In peripheral tissues, apo $\mathrm{E}$ participates in lipid homeostasis by directing lipoprotein internalization mediated by the apo $B, E(L D L)$ receptors, the expression of which can be regulated by cellular cholesterol requirements (for review, see reference 1). In addition, apo $E$ participates in the removal of cholesterol from cells by facilitating its packaging into HDL particles (7). Evidence suggests still another function for apo E. Lipoproteins containing apo E bind to lymphocytes, thereby suppressing the response of these cells to mitogens $(8,9)$. Thus, apo E containing lipoproteins may also participate in the regulation of the immune system $(10,11)$.

Apo E appears to be synthesized and secreted primarily by the liver, but unlike other apolipoproteins, it is also synthesized and secreted, to a lesser extent, by many other tissues (12-16). In a recent study by Elshourbagy et al. (16), a large variety of rat and marmoset (a small primate) tissues were screened for the presence of apo E messenger RNA (mRNA). They found that apo E mRNA was most abundant in the liver but detectable in all tissues, a finding in keeping with other studies. Tissue apo E mRNA concentrations in their study ranged from a level that was barely detectable to a level that was about one third of that found in the liver. The brain was among those tissues with the highest concentrations of apo E mRNA, with all of the major subdivisions of the brain showing approximately equal amounts. High concentrations of apo E mRNA were observed in the brain of all animals tested including humans, whereas the levels of apo E mRNA in other nonhepatic tissues varied. In this same study, the apo E mRNA in the brain was shown to be essentially the same size as that found in the liver, as was the case with the cell-free translation products of apo E mRNA from both tissues. These findings, together with results from studies indicating that there is only one copy of the apo E gene per haploid genome (17) and that liver apo E mRNA encodes a secretory protein, suggest that brain apo $\mathrm{E}$ is the same gene product as that produced by the liver and that brain apo $\mathrm{E}$, like liver apo $\mathrm{E}$, is a secretory protein. In addition, apo $\mathrm{E}$ is present in cerebrospinal fluid (18) at concentrations in excess of what would be expected for a filtered plasma protein (19). The concentration of apo $E$ in cerebrospinal fluid is $4-5 \%$ of that present in plasma, whereas the concentrations of another apolipoprotein, apo A-I, and albumin are $\sim 0.5 \%$ of that observed in plasma (18). This result is in keeping with the postulate that apo $E$ is a secretory product of the brain. 
Tissue macrophages may produce much of the apo E mRNA found in some tissues. Macrophages and monocytes maintained in culture have been shown to produce and secrete apo E (2023). However, it is unlikely that the relatively large quantities of apo E mRNA observed in the brain are produced by local macrophages. Although cells of monocytic origin and potential macrophage-like character referred to as microglia occur within the brain, these cells are few in number, small, and relatively quiescent in the normal brain. Microglia resemble conventional macrophages only when stimulated by injury or other pathologic conditions and would, therefore, seem an unlikely source of the high level of apo E mRNA observed in the normal brain.

The production by the brain of substantial quantities of what is usually considered to be a plasma protein of hepatic origin (i.e., apo E) suggests the probable importance of apo $E$ in neural physiology, particularly when one considers that neural tissue is isolated from plasma by the blood-brain barrier. As a first step in elucidating the function of apo $E$ in nervous tissue, we have established the presence of significant concentrations of apo $\mathrm{E}$ within the brain and made an initial characterization of this protein. In addition, the cells with which apo $\mathrm{E}$ is associated in both the peripheral and central nervous systems have been identified using immunocytochemical techniques. A preliminary report of this work in abstract form has previously been published (24).

\section{Methods}

Experimental procedures. Adult Sprague-Dawley rats of both sexes (230$290 \mathrm{~g}$; Simonsen Laboratories, Gilroy, CA) fed Purina rat chow were used. All animals were killed near midday. To verify results obtained from studies of the cerebral cortex, experiments were also done using normal littermates of Jimpy mice (10 g; The Jackson Laboratory, Bar Harbor, ME). Blood was thoroughly removed from pentabarbital-anesthetized animals by perfusing Medium 199 (Gibco Laboratories, Grand Island, NY) at $100-110 \mathrm{mmHg}$ through a 14-gauge canula (20-gauge for mice) inserted in the left ventricle of the heart. The perfusion was carried out with ice-cold medium for 5-7 min (250-500 ml of medium were used). Outflow was through the right auricle, which was cut before perfusion was begun. For immunocytochemical studies, perfusion was continued using a fixative $(200-300 \mathrm{ml} ; 4 \%$ formaldehyde, freshly prepared from paraformaldehyde, in $0.15 \mathrm{M}$ phosphate buffer, $\mathrm{pH} 7.4$, at $4^{\circ} \mathrm{C}$ ) for $10 \mathrm{~min}$. Then the tissue was removed and cut into $3-\mathrm{mm} \times 1$ $\mathrm{cm}$, or smaller, pieces.

Immunocytochemistry. Fixation was continued at $4^{\circ} \mathrm{C}$ for a total of $3 \mathrm{~h}$. The samples were washed in phosphate-buffered saline (PBS), cryoprotected by soaking overnight in $18 \%$ sucrose in PBS, and finally quick frozen in liquid nitrogen-cooled isopentane. Frozen blocks were stored under liquid nitrogen. Freshly prepared cryosections $(6-10 \mu \mathrm{m})$ on gelatincoated slides were placed in a blocking solution (1-3\% ovalbumin, 0.15 $\mathrm{M}$ glycine- $\mathrm{HCl}$ or ammonium acetate, and one-half strength $\mathrm{PBS}, \mathrm{pH}$ 7.4) for $30 \mathrm{~min}$ and then incubated overnight with the primary antibody diluted in $0.1-0.3 \%$ ovalbumin and $15 \mathrm{mM}$ glycine- $\mathrm{HCl}$ or ammonium acetate in PBS, pH 7.4. The primary antibodies were rabbit antisera directed against either rat apo $E$ at $1: 20,000$ to $1: 160,000$, rat apo A-I at $1: 5,000$ to $1: 20,000$, human glial fibrillary acidic protein (GFAP) at 1:5,000, rat IgG (Cappel Laboratories, Cochranville, PA) at 1:4,000, rat albumin (Cappel Laboratories) at 1:130,000 or nonimmune sera at 1:5,000. In most experiments, Triton $X-100$ at a concentration of 0.10 to $0.15 \%$ was added to the blocking solution and primary antibodies. The slides were washed overnight and then incubated in secondary antibody (affinity-purified biotinylated anti-rabbit IgG (goat); ABC Kit, Vector Laboratories, Inc., Burlingame, $\mathrm{CA}$ ) for $3 \mathrm{~h}$ according to the recommended dilution, followed by a 2-h wash and 3-h incubation in an avidin-biotin complex made with twice the recommended avidin, followed by a 2- to 16-h wash. To detect the presence of peroxidase, the sections were preincubated for $15-30 \mathrm{~min}$ with diaminobenzidine $(0.2$ $\mathrm{mg} / \mathrm{ml}$ ) in $0.10 \mathrm{M}$ monobasic phosphate brought to $\mathrm{pH} 7.0$ with $\mathrm{NH}_{4} \mathrm{OH}$, reacted for $2 \mathrm{~min}$ in the presence of $0.01 \mathrm{M} \mathrm{H}_{2} \mathrm{O}_{2}$, and then washed. Slides were left unstained, or nuclei were counterstained with Gill's hematoxylin. All steps that required more than $3 \mathrm{~h}$ were performed at $4^{\circ} \mathrm{C}$; shorter incubations were performed at room temperature. Because apo $E$ and apo A-I are present in serum, we initially avoided the use of serum as a blocking agent. However, no interference was observed after goat serum at a 1:50 dilution was added to the blocking step or to the primary antibody. Because the addition of serum reduced background staining, it was used in subsequent studies. Occasional lots of ovalbumin caused problems with the avidin-biotin-based antibody detection system used in this study. These problems were probably attributable to contamination by egg white avidin.

To establish the specificity of the immunocytochemical reaction, each reagent used in the procedure was omitted in turn. Under these conditions, there were no peroxidase reaction products observed in nervous tissue. Controls using nonimmune rabbit sera were also negative.

The same tissue was used for electron microscopy that had been used for the light level work. In addition, a second group of tissues fixed for only $5 \mathrm{~min}$ with $0.5 \%$ glutaraldehyde added to the $4 \%$ formaldehyde fixative were also employed. This latter fixative, with its improved preservation, allowed the detection of extracellular apo $E$ but was not suitable for detecting intracellular antigen. All tissues were cryoprotected and frozen as described above for the light level work. Thick $(20 \mu \mathrm{m})$, frozen sections incubated in suspension were used for immunocytochemistry as previously reported (25). The only change from this earlier procedure was the addition of $0.05-0.5 \%$ saponin to all solutions and the use of a peroxidase-coupled $\mathrm{F}\left(\mathrm{ab}^{\prime}\right)_{2}$ fragment directed against rabbit IgG supplied by BIOSYS S. A. (Compiègne, France).

Characterization of apo $E$ and apo A-I. Proteins were extracted from tissue and serum by homogenization with a detergent-containing buffer (0.5\% Nonidet-P40, $120 \mathrm{mM} \mathrm{NaCl}$, and $50 \mathrm{mM}$ Tris-HCl, $\mathrm{pH} 8.5$ ). Apo E was precipitated from the $100,000 \mathrm{~g}$ supernatant of this extract by Staphylococcus aureus Protein A (IgGSORB; The Enzyme Center, Boston, MA) and the same immune rabbit serum that was used in the immunocytochemical studies. The pellet was washed with $50 \mathrm{mM}$ Tris buffer (pH 7.4) that contained $100 \mathrm{mM} \mathrm{NaCl}, 500 \mathrm{mM} \mathrm{LiCl}$, and $1 \%$ Nonidet-P40 and was sedimented by centrifugation $(5 \mathrm{~min}, 1,000 \mathrm{~g}$ ). Gel application buffer that contained $\beta$-mercaptoethanol was added to the pellet, and the samples were then electrophoresed on $10 \%$ polyacrylamide slab gels that contained sodium dodecyl sulfate (SDS) (26).

Proteins were electrophoretically transferred from the gel to nitrocellulose paper using a constant current of $300 \mathrm{~mA}$ for $3 \mathrm{~h}$ at $4^{\circ} \mathrm{C}$. The transfer buffer was a slightly modified version of that described by Towbin et al. (27) and contained $25 \mathrm{mM}$ Tris, $192 \mathrm{mM}$ glycine, $20 \%$ methanol, and $2.5 \%$ isopropanol ( $\mathrm{pH} \mathrm{8.3)}$. After the blots had been incubated with $3 \%$ gelatin in Tris-buffered saline ( $\mathrm{pH} 7.5$ ), they were incubated overnight with a 1:250 dilution of the immune serum in Tris-buffered saline that contained $1 \%$ gelatin and $0.5 \%$ Tween 20 (incubation buffer; Bio-Rad Laboratories, Richmond, CA). The blot was then washed five times (5 min for each wash) with the incubation buffer and reacted for $3 \mathrm{~h}$ with incubation buffer that contained ${ }^{125}$ I-labeled Protein A (Pharmacia Fine Chemicals, Uppsala, Sweden) $\left(3.75 \times 10^{6} \mathrm{cpm} / \mu \mathrm{g} ; \sim 0.24 \mu \mathrm{g}\right.$ of Protein $\mathrm{A} / \mathrm{ml}$ ). The blot was washed five times as before, and immunoreactive bands were visualized by autoradiography.

To obtain a semiquantitative estimate of the amount of apo $E$ present in the extracts from rat brain and liver, the total extracts were run on $10 \%$ polyacrylamide slab gels in SDS and blotted. Rat serum and a range of concentrations of rat $\mathrm{HDL}_{1}(28)$ were run in parallel. The proteins were detected with immune serum and ${ }^{125} \mathrm{I}$-labeled Protein A. Autoradiograms were developed, the areas corresponding to apo $\mathrm{E}$ in the $\mathrm{HDL}_{1}$, in the brain extract, in the liver extract, and in the serum were cut from the gels, and the silver grains were eluted and quantitated as described 
(29). A standard curve, which was prepared using known concentrations of $\mathrm{HDL}_{1}$ (a lipoprotein containing predominantly apo E), was used to quantitate the amounts of apo $\mathrm{E}$ in the extracts and plasma.

\section{Results}

Identification and characterization of apo $E$ in the brain. To identify apo $\mathrm{E}$ within the brain of the rat and to evaluate the thoroughness of the tissue perfusion in eliminating plasma apo E contamination, apo $\mathrm{E}$ and apo A-I were immunoprecipitated from extracts of the brain and other tissues and analyzed by gel electrophoresis and immunoblotting. Apo A-I is an appropriate control inasmuch as apo A-I and apo $\mathrm{E}$ are both present on the same lipoprotein particles in the plasma, and although apo A-I is smaller, it is present at a higher concentration within the plasma (2) than apo E. In addition, there is no evidence that apo A-I is
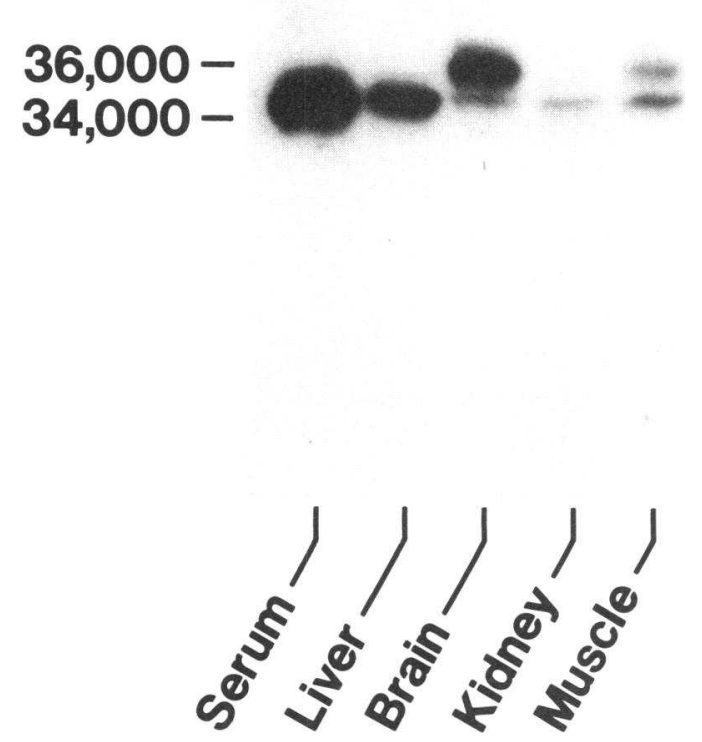

Figure 1. Autoradiogram of an immunoblot of rat apo E immunoprecipitated from extracts of tissue and plasma. produced by the brain (16). Tissue extracts of the brain were compared with those of the liver (the principal source of plasma apo $E$ and one source of plasma apo A-I), kidney (a well-perfused organ that has low levels of apo E mRNA in these animals), skeletal muscle (a tissue rich in blood vessels and poorly perfused in the resting state), and serum. Immunoprecipitated apo E from serum and liver appeared as a single band of $M_{\mathrm{r}}$ $\sim 35,000$ (Fig. 1). However, apo $\mathrm{E}$ from the brain was predominantly a band of $M_{\mathrm{r}} \sim 36,000$, with only a faint band of $M_{\mathrm{r}}$ $\sim 35,000$. In contrast, the kidney appeared to possess only small quantities of the lower molecular weight form, whereas muscle tissue displayed both forms in small quantities (Fig. 1). The differences observed in the immunoprecipitation patterns of apo $E$ from peripheral tissue and from serum indicate that apo $E$ from peripheral tissue does not represent a plasma contaminant. Moreover, the higher apparent molecular weight of brain apo $\mathrm{E}$ suggests that it is a tissue product distinct from serum apo $\mathrm{E}$. In support of this hypothesis is the finding that brain apo $E$ isolated from the cerebrospinal fluid of humans is multiply sialylated and has an apparent higher molecular weight presumably owing to the high level of glycosylation (K. H. Weisgraber and R. W. Mahley, personal communication).

Immunoprecipitable apo A-I from serum and liver appeared as a single band of $M_{\mathrm{r}} \sim 28,000$. While the liver contained small quantities of apo A-I, no apo A-I could be detected in the brain.

To gain a semiquantitative estimate of the amount of apo E present in liver and brain tissues, gel electrophoresis and immunoblotting (as detailed in Methods) were used to compare extracts of liver and brain with a known apo E concentration. The liver was found to contain approximately twice the level of apo E present in the brain (54 $\mu \mathrm{g} / \mathrm{g}$ of liver, $21 \mu \mathrm{g} / \mathrm{g}$ of brain). This ratio is similar to the relative ratios of apo E mRNA observed in these two tissues (3:1) by Elshourbagy et al. (16). The concentration of apo $\mathrm{E}$ in serum, as determined by this procedure, was $\sim 260 \mu \mathrm{g} / \mathrm{ml}$, which is in agreement with previous data (30).

Immunocytochemical localization of apo $E$ in the brain. Frozen cryostat sections of formaldehyde-fixed rat brain were examined by light microscopy for the presence of immunoreactive apo E. As a control for plasma contamination, apo A-I was also investigated. Phase-contrast micrographs of unstained sections and bright-field images of stained and unstained sections showed that immunoreactive apo $\mathrm{E}$, identified by a dark peroxidase reaction product, appeared in unique sites and within distinctive cells of the nervous tissues. In all of the major subdivisions of the brain (cerebrum, cerebellum, pons, medulla, and spinal cord), reactive cells were identified as astrocytes of both the fibrous and protoplasmic variety (Fig. 2). The criteria used to classify cells as astrocytes (a major glial cell class) were general shape (usually stellate with long cytoplasmic processes), nuclear morphology (intermediate size and staining intensity with no obvious nucleolus and an irregular contour), and distribution (processes abutting blood vessels and the brain surfaces).

Antibodies directed against the astrocyte-specific protein GFAP recognized most of the same astrocyte cells. The reaction product for apo $\mathrm{E}$ was of equal intensity for protoplasmic astrocytes of gray matter and fibrous astrocytes of white matter, however, there was an unequal distribution of GFAP among different types of astrocytes. Fibrous astrocytes displayed intense GFAP reaction product, whereas most of the protoplasmic astrocytes were not intensely stained, and some were unstained. One ex- 

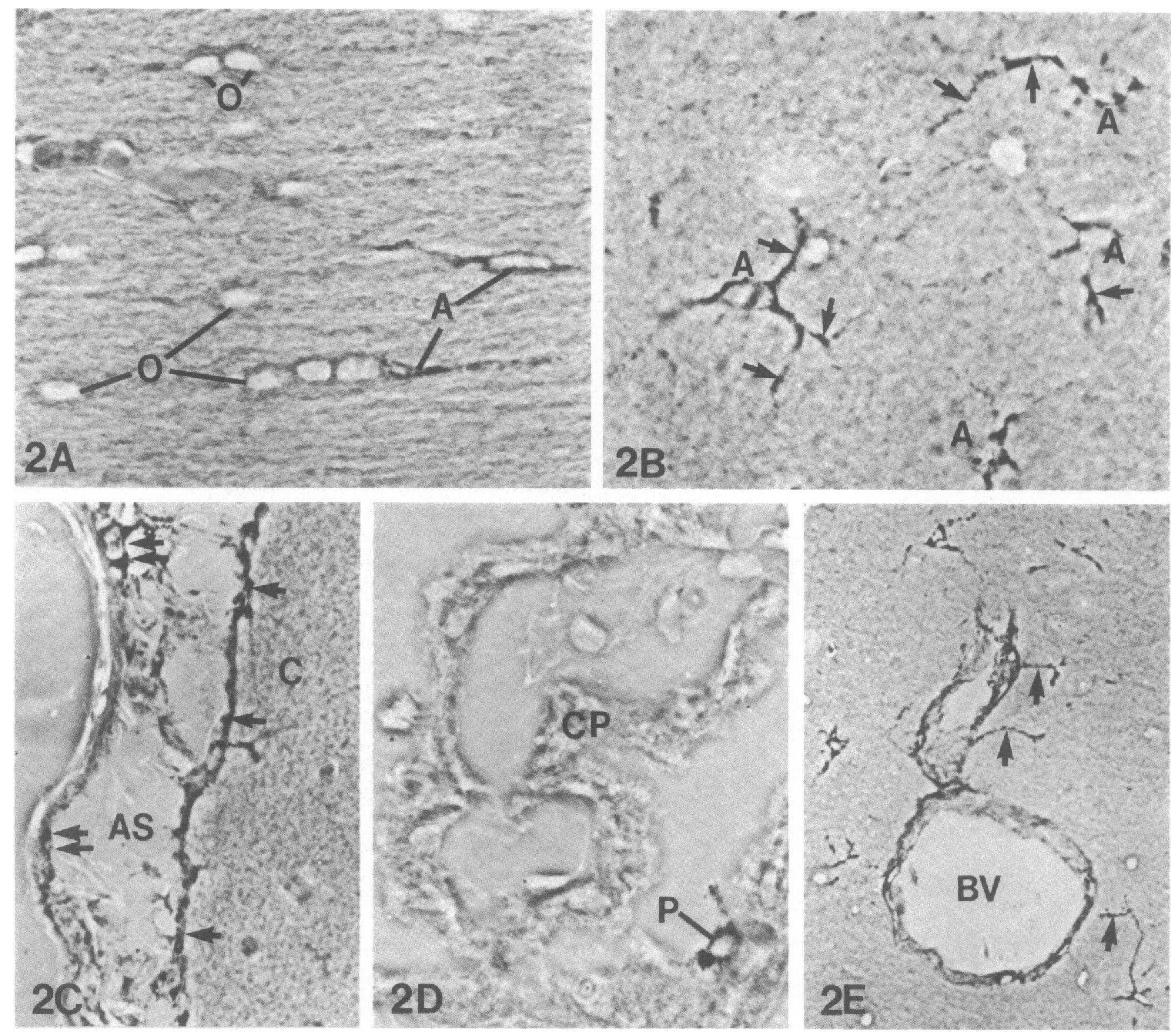

Figure 2. Phase-contrast micrographs of unstained sections of rat cerebrum reacted for apo $\mathrm{E}$ (dark reaction product). $(A)$ Unreactive oligodendroglia $(\mathrm{O})$, as well as reactive fibrous astrocytes $(\mathrm{A})$ are seen between fiber bundles of the white matter $(\times 710)$. (B) Protoplasmic astrocytes (A) of the gray matter are shown with dark perinuclear reaction product, as well as with reaction product in some of their processes (arrows) $(\times 695)$. (C) A dense layer of reaction product (ar-

ception was that protoplasmic astrocytes near the pia mater, which have an abundance of fibers, reacted strongly with the GFAP antiserum (Fig. 3). The variability of GFAP reactivity among astrocytes is well documented in the literature (31-36).

Immunoreactive apo $\mathrm{E}$ was seen around the nucleus of all morphologically identifiable astrocytes within both the white and gray matter and at the surface of the brain (Figs. 2 and 3). In the lateral ventricles, neither the cells of the choroid plexus nor the ependymal cells were positive for apo E, with the exception of a few cells at the extreme anterior and posterior horns of the lateral ventricles where the layer of ependymal cells may be incomplete. Astrocytic foot processes ending on basement membranes, which occurs at the surface of the neural tissue rows) is present at the surface of the cerebrum $(C)(\times 280)$. Reaction product is also associated with the cells (double arrows) of the arachnoid space (AS). (D) Cells of the choroid plexus (CP) are not reactive, but occasional positive cells $(P)$ are seen on their surfaces $(\times 1,110)$.

$(E)$ Larger blood vessels (BV) are lined by reaction product. Astrocytic cell processes (arrows) extending to these vessels are also reactive $(\times 270)$.

below the pia mater and along large vessels or capillaries, were often rich in immunoreactive apo $\mathrm{E}$. In addition, apo $\mathrm{E}$ was associated with pial cells and fibers within the arachnoid space and the continuation of the arachnoid space around large vessels, but not with cells of the dura mater. Many of the cells in the arachnoid are phagocytic macrophages (37), which could be expected to be reactive, while others are the very flat pial cells of neural crest origin $(37,38)$. Apo E was not detected within vascular endothelium or smooth muscle cells, although, occasional cells with dense nuclei accompanying capillaries, possibly macrophages, were positive. However, by far the greatest number of reactive cells were astrocytes.

Immunoreactive apo $\mathrm{E}$ was not found to be associated with 


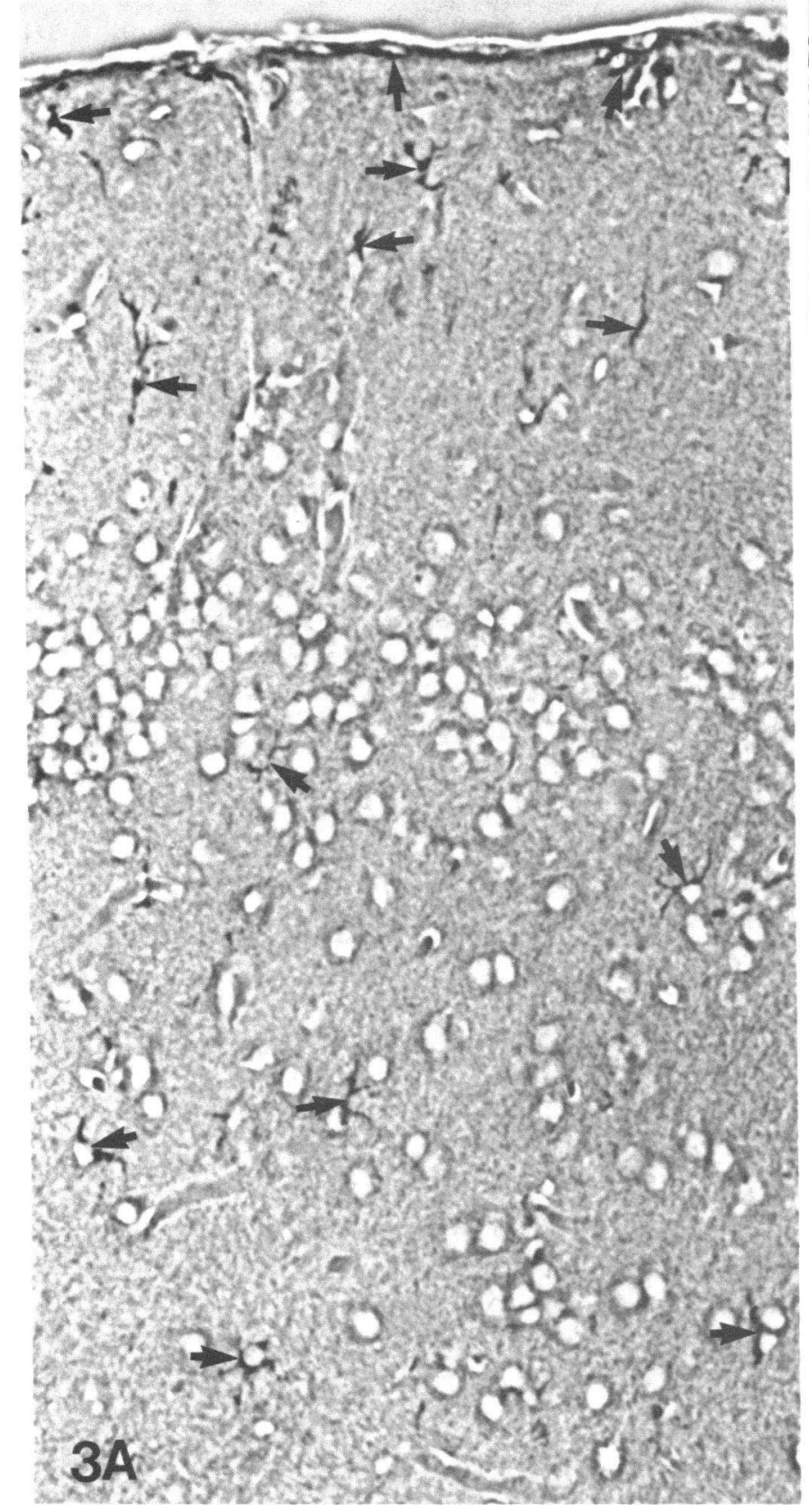

Figure 3. $(A)$ Phase-contrast micrograph of an unstained section of mouse cerebrum reacted for apo $\mathrm{E}$ (dark reaction product). Reactive astrocytes and their processes (arrows) are seen randomly throughout the section $(\times 350)$. (B) Phase-contrast micrograph of an adjacent, un-

another major class of glial cells, the oligodendroglia, which were identified by their morphology and their association with myelinated fiber tracts and neurons in specific regions of the brain. In addition, the microglia, which possess small dense nuclei, were seldom, if ever, found to possess apo E. Apo E was also not present in neurons or neuronal processes.

A very weak granular reaction for apo A-I at extremely high antibody concentrations was seen in astrocytes and astrocytic foot processes that form the glial limitans (Fig. 4). Reactive astrocytic processes were also seen a little deeper along some blood vessels. No reaction was seen in cells of the ependyma or choroid plexus or in astrocytes deeper within the brain. The leaky vessels

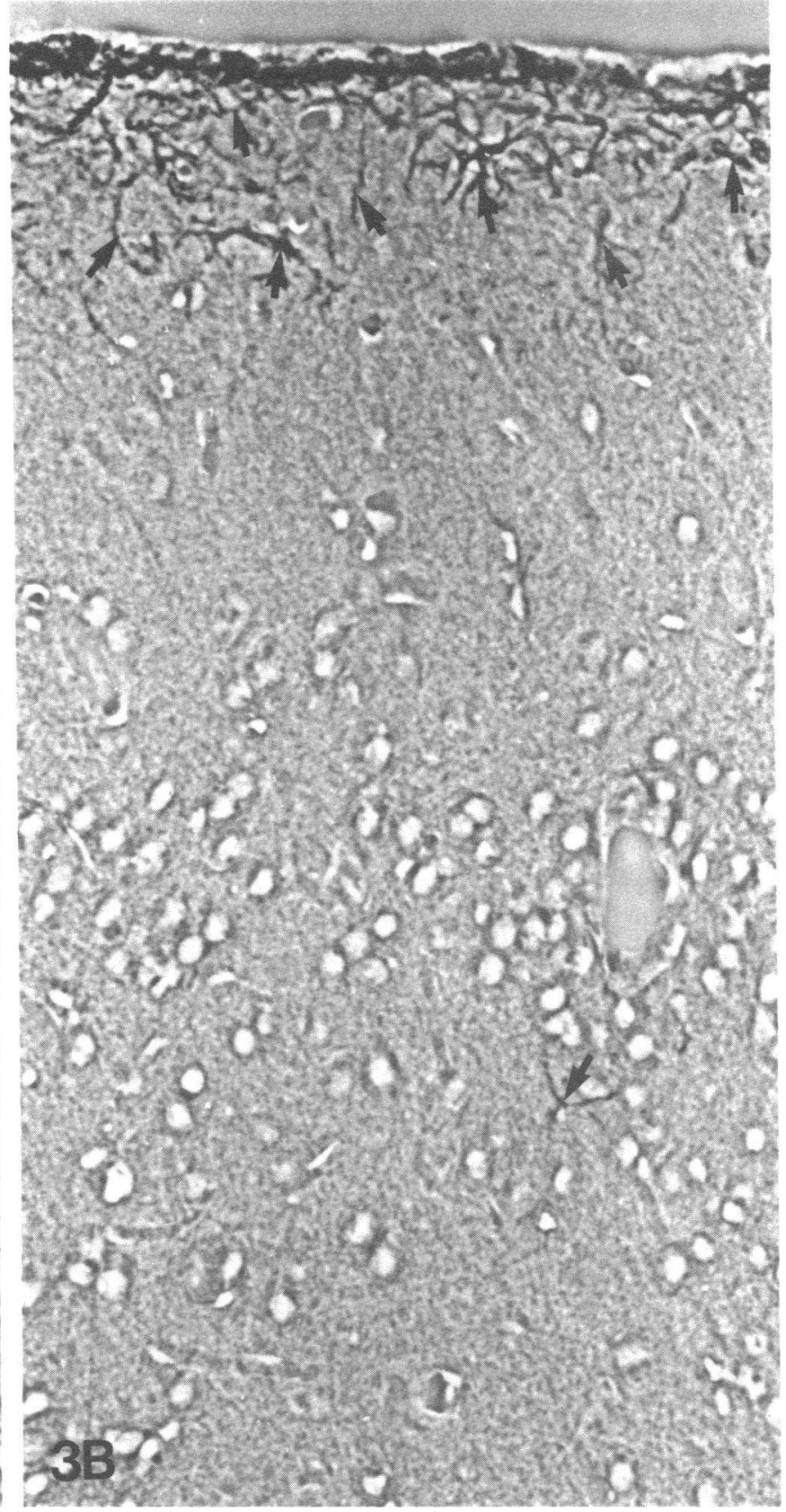

stained section of the same cerebrum reacted for GFAP (dark reaction product). Reactive astrocyte processes (arrows) are seen primarily at the cerebral surface $(\times 350)$.

of the meninges, which are outside of the blood-brain barrier, were the probable source of the plasma apo A-I that reached astrocytes just below the pia mater. The presence of albumin and IgG in a diffuse pattern in this region (data not shown) confirmed this supposition.

Several specialized or distinctive cells that have characteristics in common with astrocytes have been identified in the central nervous system. These include the Bergmann glia, tanycytes, pituicytes, and Müller cells. These cells are similar to astrocytes in their embryology, in their relationship to other cells, particularly blood vessels and neural tissue surfaces $(37,39-43)$, and in their ability to be stained by specific metal impregnation tech- 


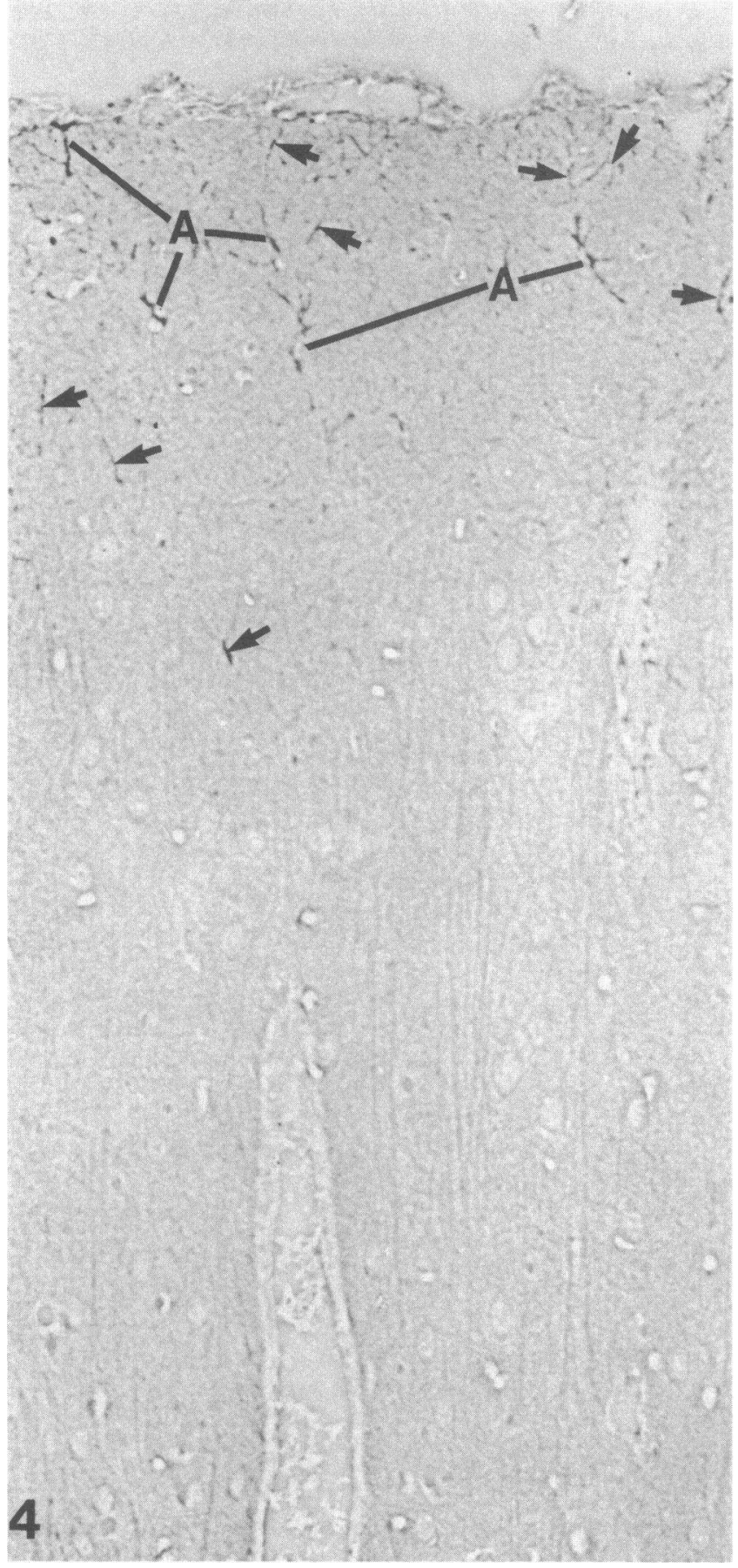

Figure 4. Phase-contrast micrograph of an unstained section of rat cerebrum reacted for apo A-I (dark reaction product). Astrocytes (A) and astrocyte processes (arrows) containing apo A-I are only found adjacent to the cerebral surface. Deeper within the cortex, the astrocytes and their processes, like the rest of the neural tissue, are not reactive $(\times 300)$.

niques $(39,41,43)$. They also contain the astrocyte-specific protein GFAP $(31,32,34-36,44-49)$. The similarities between these cells and typical astrocytes has suggested that they may be morphologically distinct forms of astrocytic glia. They were, therefore, evaluated for the presence of apo $\mathrm{E}$.

The nuclei of the Bergmann glia are located between the giant Purkinje cells of the cerebellum (42). These glial cells pos-

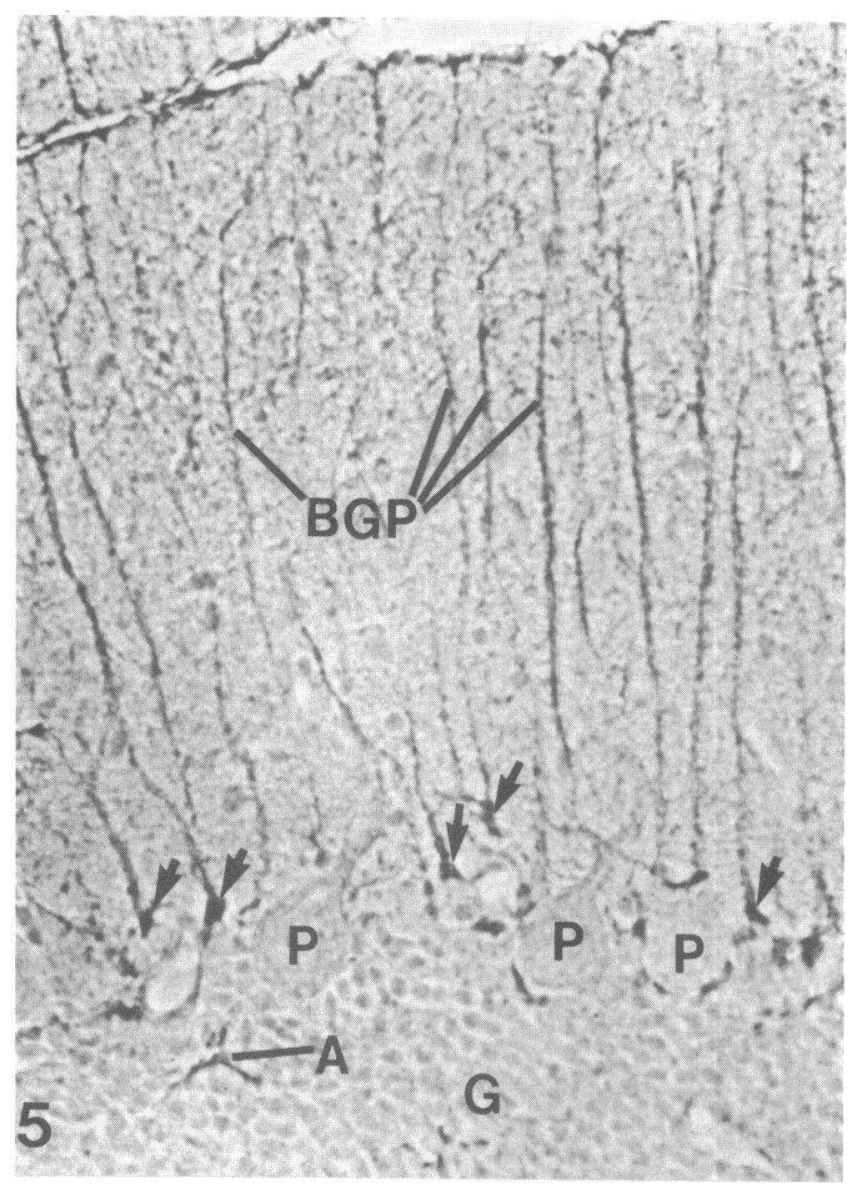

Figure 5. Phase-contrast micrograph of an unstained section of rat cerebellum reacted for apo $\mathrm{E}$ (dark reaction product). Giant unreactive Purkinje cells $(\mathrm{P})$ are surrounded by smaller Bergmann glia. Intense reaction for apo $\mathrm{E}$ is seen above the nuclei of the Bergmann glial cells (arrows). Reactive cell processes of the Bergmann glia (BGP) traverse the molecular layer and line the surface of the cerebellum. Typical reactive astrocytes (A) are found among the cells of the granular layer (G) $(\times 345)$.

sess a few long processes that extend to the surface of the cerebellum, where a basement membrane is present. The Bergmann glia were intensely immunoreactive for apo $\mathrm{E}$ (Fig. 5).

Tanycytes occur within the wall of the third ventricle in the region between the optic chiasm and the pituitary $(37,41,43$, 46). Pituicytes occur among the neural cell process within the neural stalk and lobe of the pituitary $(47,48)$. Along the lateral walls of the third ventricle, tanycytes occur singly or in clusters. They reach between ependymal cells to make contact with the cerebrospinal fluid and send long foot processes deep into the brain or traverse the median eminence at the emergence of the pituitary to reach the neural surface below. Tanycytes are long, not stellate, but like other astrocytes, their foot processes frequently end on blood vessels. In the region of the median eminence and the recessus infundibularis, these vessels are part of the portal blood system that supplies the pituitary. This region and the neural lobe of the pituitary are two of the few places in the brain without a blood-brain barrier. As shown in Fig. 6, tanycytes were immunoreactive for apo $\mathrm{E}$, whereas most of the ependymal cells next to them were not. Two patterns of reactivity were seen: those tanycyte processes from the lateral wall reaching 

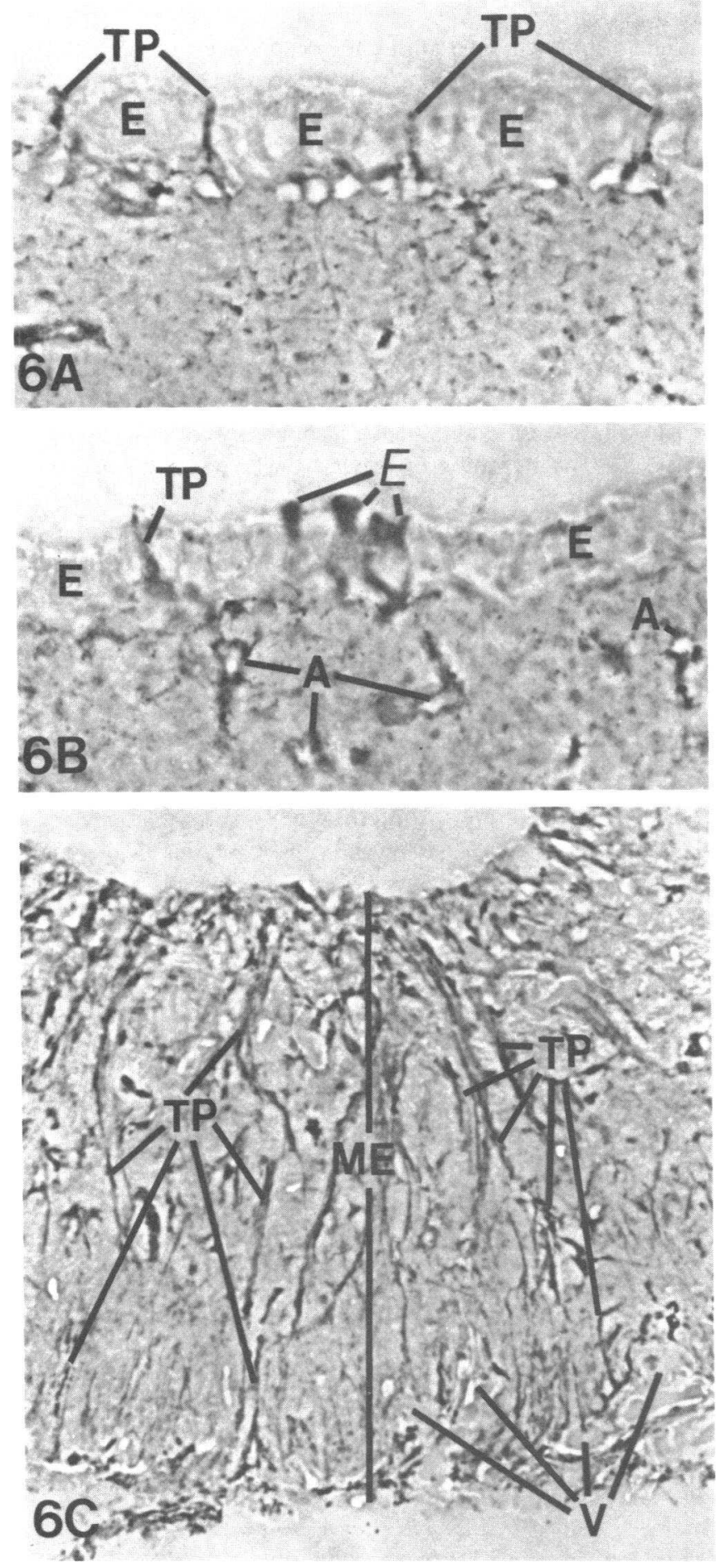

Figure 6. Phase-contrast micrographs of unstained sections of the third ventricle of the rat reacted for apo $\mathrm{E}$ (dark reaction product). $(A)$ Tanycyte cell processes (TP) among the ependymal cell layer (E) of the lateral wall are reactive for apo $\mathrm{E}$, whereas processes reaching into the brain are not reactive and are, therefore, poorly distinguished from the rest of the neural tissue $(\times 695)$. $(B)$ While ependymal cells $(E)$ usually do not react for apo $\mathrm{E}$, occasional reactive cells are found $(E)$ in this region. Tanycyte cell processes (TP) reaching the ventricle and astrocytes (A) within the neural tissue are reactive for apo $E(\times 695)$. $(C)$ In the floor of the third ventricle at the median eminence (ME), tanycytes replace ependymal cells and form the lining of the ventricle. The very numerous apo E-reactive cell processes of these tanycytes (TP) can be seen traversing the thin neural tissue to reach the external surface of the brain and the numerous blood vessels $(\mathrm{V})$ of this region $(\times 330)$.

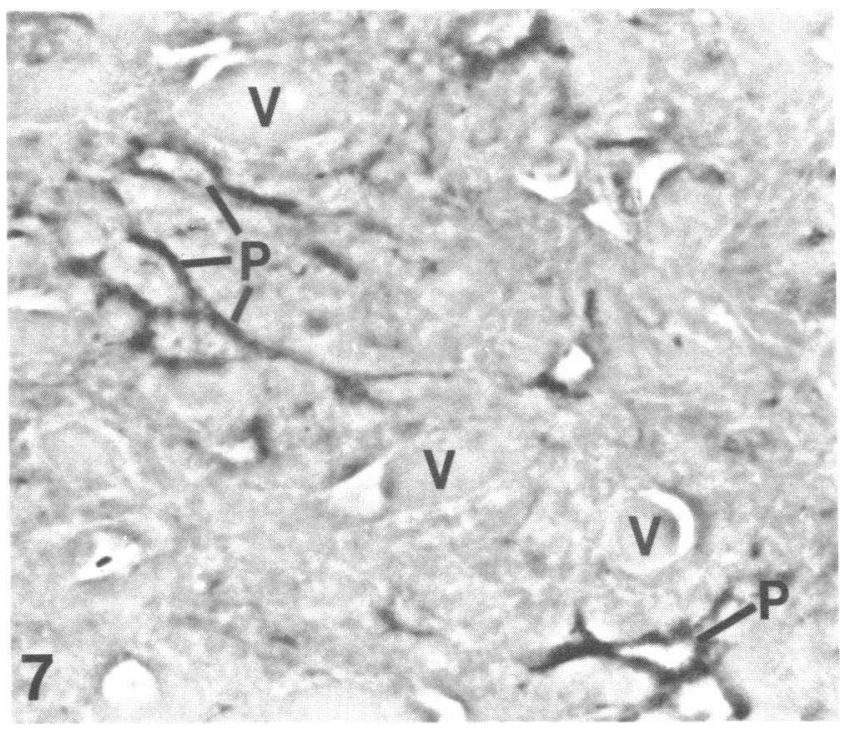

Figure 7. Phase-contrast micrograph of an unstained section of the neural lobe of the rat pituitary reacted for apo $E$ (dark reaction product). Reactive pituicytes $(\mathrm{P})$ are seen among the unreactive vascular cells of the numerous blood vessels $(V)$ in this region $(\times 850)$.

deep into the brain were not reactive, whereas processes from tanycytes in the floor of the ventricle reaching into the area of the median eminence were reactive. The pituicytes were the only reactive cells of the neural portion of the pituitary (Fig. 7).

Apo A-I was not detectable in the pituicytes or tanycytes of this region despite the absence of a blood-brain barrier and despite the intense but noncellular reaction for albumin and $\mathrm{IgG}$ in this area of the brain. However, the more conventional astrocytes within the ventrolateral walls of the third ventricle surrounding this area of greater permeability were weakly reactive at high antibody concentrations (Fig. 8). This reaction product was present as granules within the cell processes.

Within the retina, which is an extension of the central nervous system, the major glial element is the Müller cell $(39,40)$. Müller cell processes traverse the retina, making junctional contact with the receptor cells at the outer edge of the outer nuclear layer, just above the rods and cones, and with one another at the inner limiting membrane or surface of the retina, where a basement membrane that separates the retina from the aqueous and vitreous humor is present. As shown in Fig. 9, $A$ and $B$, the cell bodies of the Müller cells within the inner nuclear layer of the retina contained apo $\mathrm{E}$. The radial processes of Müller cells that pass through the inner plexiform layer to the inner limiting membrane were also immunoreactive for apo E. Fewer of the processes passing through the outer plexiform layer were reactive, and no reactivity was seen in processes deep among the nuclei of the receptor cells. Occasional, more conventional astrocytic glia along the blood vessels or among the ganglion cells were also reactive for apo E. No other cells of the retina, including the pigment epithelial cells, were positive; however, the choroid sometimes showed diffuse reactivity.

Reactivity for apo A-I was observed along the inner limiting membrane of the retina (Fig. $9 C$ ). The reaction product was generally granular and appeared within Müller cell processes or around the nuclei of the more conventional astrocytes present among the ganglion cells. A granular reaction for apo A-I was also observed within cells of the ciliary process and the inner aspect of the iris. 


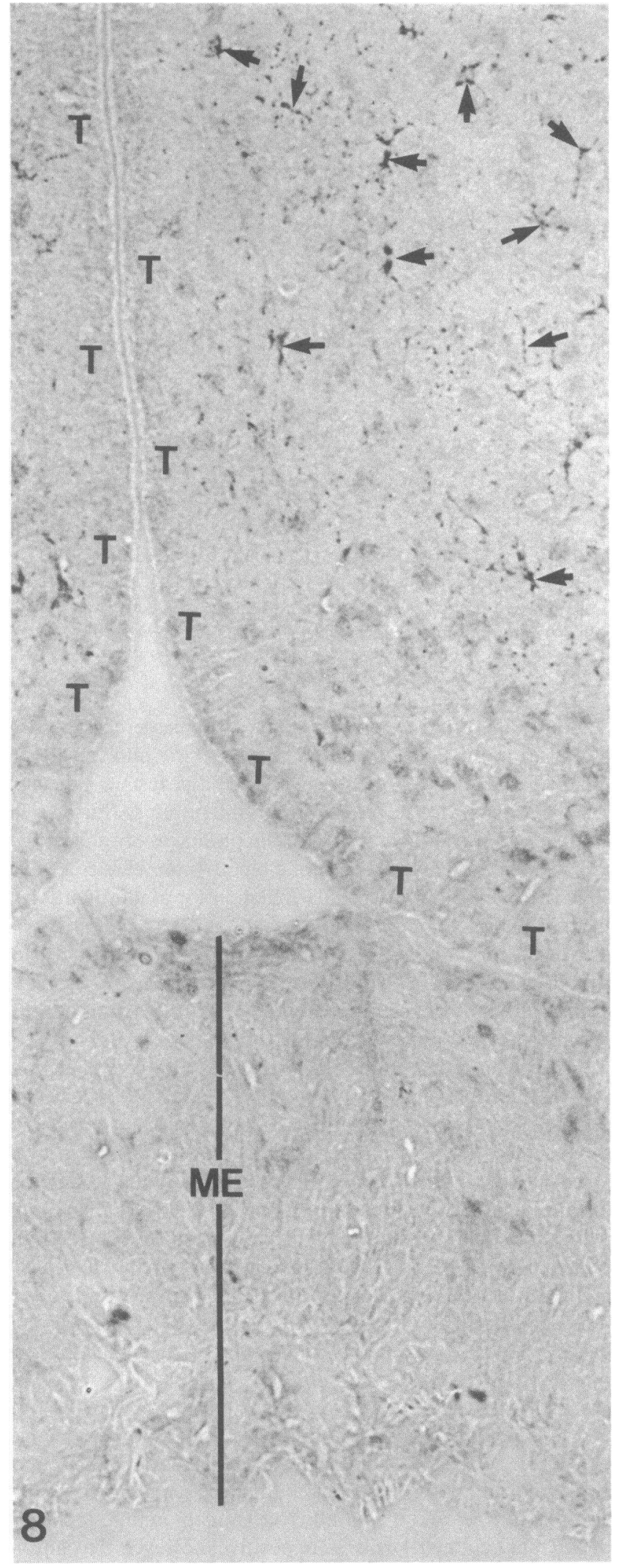

Figure 8. Phase-contrast micrograph of an unstained section of the third ventricle of the rat reacted for apo A-I (dark reaction product). The tanycytes that traverse the median eminence (ME) and the tanycytes $(\mathrm{T})$ that line the lateral walls of the third ventricle show no reactivity for apo A-I above the background reactivity present at these high antibody concentrations. The more conventional astrocytes bordering this region, however, contain dark granules of apo A-I reaction product (arrows) $(\times 315)$.
Electron microscopic detection of apo $E$ in the brain. The results of the light level immunocytochemical studies strongly suggested that apo E was a secretory product of all astrocytic cells. If this were the case, one would expect the intracellular apo E detected in these cells to be in compartments associated with secretion, that is, within the rough endoplasmic reticulum, Golgi apparatus, and secretory vesicles. To investigate this possibility, electron microscopic immunohistochemical techniques were used to examine the Bergmann glial epithelial cells of the cerebellum, which were chosen because they are densely and regularly arrayed, a characteristic that greatly simplifies the location of cells or regions of cells. Preembedding techniques and peroxidase-coupled antibodies (as outlined in Methods) were used. Apo $\mathrm{E}$ was found in the Golgi apparatus of the Bergmann glia (Fig. $10 A$ ). In addition, irregular vesicles within the processes of these cells were positive (Fig. $10 \mathrm{~B}$ ). At the external surface of the cerebellum, extracellular reaction product was present between nerve cell and glial cell processes, as well as within the basement membrane at the glial limitans. Occasional cells along blood vessels, which were tentatively identified as macrophages, showed reaction product in large and small vacuoles (Fig. $10 C$ ).

Immunocytochemical localization of apo $E$ in the peripheral nervous system. Whereas the brain and spinal cord are formed from the neural tube, the peripheral nervous system is derived from neural crest cells. Within this system at least four types of glial cells are recognized: Schwann cells that resemble oligodendroglia and produce the myelin of the peripheral system; Schwann cells that enwrap small nerve fibers but do not produce myelin; satellite cells, which encapsulate the sensory and motor neurons of ganglia; and enteric glia, which accompany the enteric nerve network. Of these four, only the enteric glia have consistently been reported to contain a protein that cross-reacts with antibodies directed against $\operatorname{GFAP}(50,51)$. In addition, a subset of satellite cells and nonmyelinating Schwann cells may also contain a GFAP-like protein (52-54). To determine whether apo $\mathrm{E}$ was present in these cells, the cervical dorsal root (or spinal) ganglia, superior cervical ganglion of the sympathetic trunk, and enteric ganglia of the duodenum, each with their associated nerves, as well as the brachial plexus and sciatic nerve, were examined.

All satellite cells surrounding the giant sensory nerve cells of the cervical dorsal root ganglia were found to be reactive for apo E (Fig. $11 A$ ). However, GFAP was not present in these cells. The less well-organized satellite cells surrounding the smaller motor neurons of the superior cervical ganglion were also all reactive for the presence of apo $\mathrm{E}$ (not shown). Furthermore, as shown in Fig. $11, B$ and $C$, the enteric ganglia and nerve network showed strong apo $\mathrm{E}$ immunoreactivity. In stained sections, where the cell nuclei of the enteric ganglia could be identified, this reactivity appeared to be associated with glia but not with the neurons or the fibroblasts that envelope the ganglia.

In the sympathetic trunk, which is composed almost exclusively of unmyelinated nerve fibers, weak perinuclear reaction for apo E was associated with the Schwann cells (Fig. 11 D). Reaction was also seen along the nerve fiber bundles and along the endoneurium, particularly near ganglia. Within the spinal nerves, which have both myelinated and unmyelinated fibers, reactive Schwann cells were associated with nonmyelinated but not myelinated fibers. The nerve fibers and endoneurium of spinal nerves were not reactive. The tentative identification of apo E-containing Schwann cells as nonmyelinating cells is further supported by results from studies of nerves that extend into the 

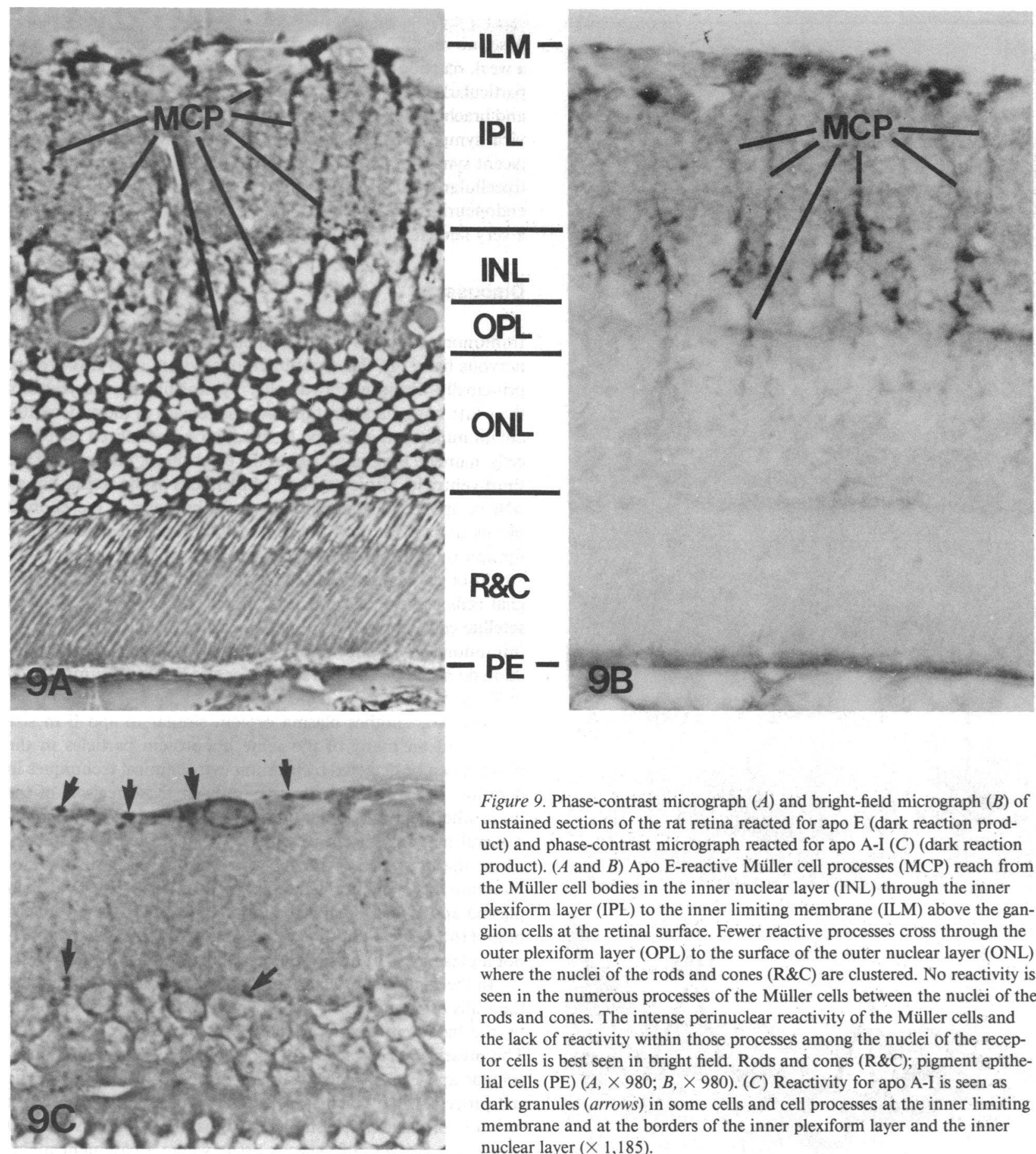

Figure 9. Phase-contrast micrograph $(A)$ and bright-field micrograph $(B)$ of unstained sections of the rat retina reacted for apo $\mathrm{E}$ (dark reaction product) and phase-contrast micrograph reacted for apo A-I $(C)$ (dark reaction product). ( $A$ and $B$ ) Apo E-reactive Müller cell processes (MCP) reach from the Müller cell bodies in the inner nuclear layer (INL) through the inner plexiform layer (IPL) to the inner limiting membrane (ILM) above the ganglion cells at the retinal surface. Fewer reactive processes cross through the outer plexiform layer (OPL) to the surface of the outer nuclear layer (ONL) where the nuclei of the rods and cones $(\mathrm{R} \& \mathrm{C})$ are clustered. No reactivity is seen in the numerous processes of the Müller cells between the nuclei of the rods and cones. The intense perinuclear reactivity of the Müller cells and the lack of reactivity within those processes among the nuclei of the receptor cells is best seen in bright field. Rods and cones (R\&C); pigment epithelial cells (PE) $(A, \times 980 ; B, \times 980)$. (C) Reactivity for apo A-I is seen as dark granules (arrows) in some cells and cell processes at the inner limiting membrane and at the borders of the inner plexiform layer and the inner nuclear layer $(\times 1,185)$.

extremities. In both the sciatic nerve and the brachial plexus, which have a limited number of unmyelinated fibers, apo Ereactive Schwann cells were rarely seen.

Occasional reactive cells closely associated with the blood vessels were found in all the nerves and large ganglia. These cells, which tended to have a coarse granular reaction for apo $\mathrm{E}$, appeared to be macrophages accompanying these vessels. None of the glial cells in any of the peripheral nervous tissue showed reactivity for apo A-I.

Extracellular apo $E$. To determine if any apo E or apo A-I was extracellular, the original immunocytochemical studies were repeated without the presence of detergents. In these nonper- meabilized sections, astrocytic cells and their processes were not reactive as would be expected if apo $\mathrm{E}$ were intracellular. However, a large concentration of apo $\mathrm{E}$ was associated with cells and fibers in the space around large blood vessels, in the arachnoid, and at the glial limitans, demonstrating that extracellular apo $\mathrm{E}$ was present in these spaces. Thus, the apparent positive reaction for apo $\mathrm{E}$ that was seen in the flat pial cells in permeabilized sections may have represented absorbed protein on cell surfaces or in the matrix on which these thin cells sit rather than a true intracellular reaction. However, the more rounded phagocytic cells of the arachnoid contained intracellular apo E. No positive reaction for extracellular apo $\mathrm{E}$ was seen in the eye. 

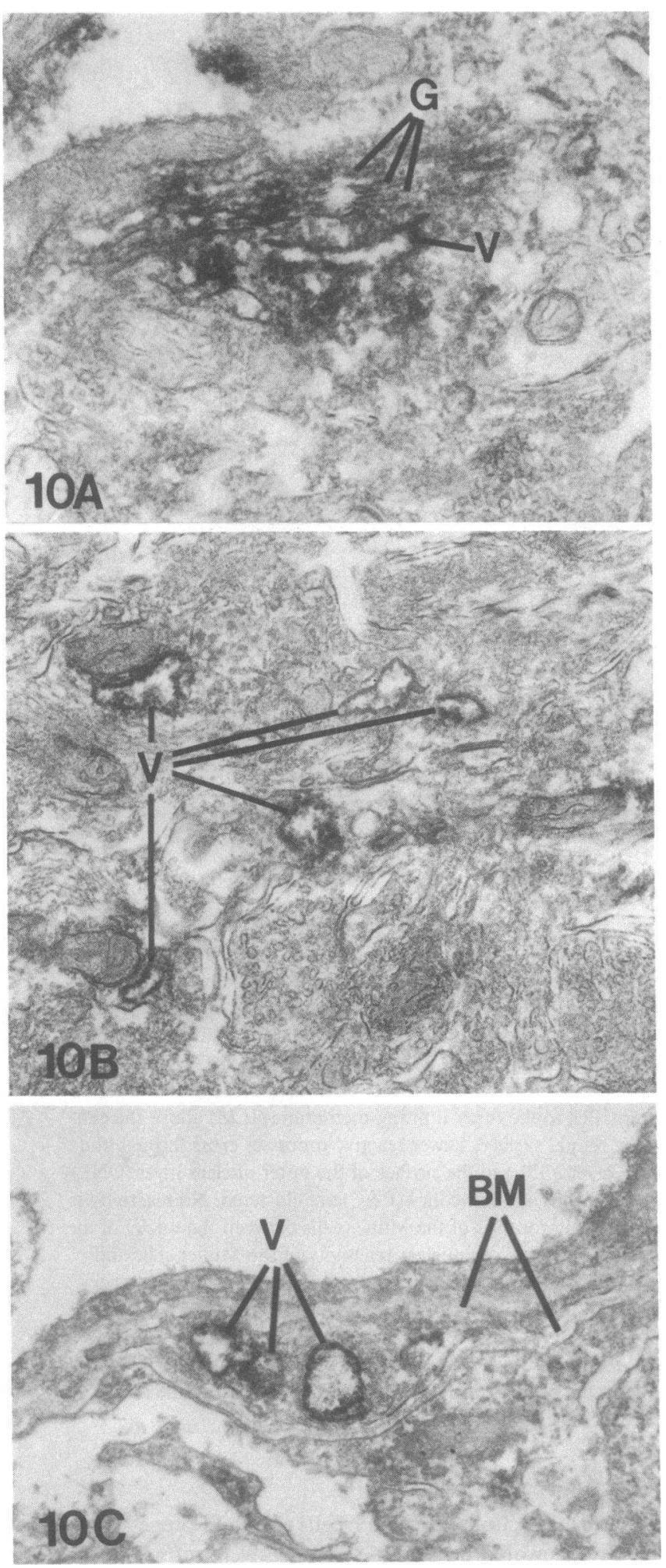

Figure 10. Electron micrographs of rat cerebellar tissue reacted for apo $\mathrm{E}$ (dark reaction product). $(A)$ The reaction product is seen in the stacks of the Golgi apparatus (G) and associated vesicles (V) within Bergmann glial cells. The bleeding of this reaction product into the nearby cytoplasm is due to the extensive disruption of the membranes by saponin. Cells that were not as disrupted showed little reaction, presumably due to the lack of antibody penetration $(\times 34,000)$. $(B)$ Within the processes of the Bergmann glial cells, reactivity for apo $E$ is also seen in numerous, irregular, small vesicles $(\mathrm{V})(\times 30,000) .(C)$ Reaction product in larger vesicles $(\mathrm{V})$ resembling lysosomes is some-
Also, no reaction was observed in the enteric ganglia, and only a weak reaction was present in some areas of the spinal ganglia, particularly around blood vessels. The spinal nerve, sciatic nerve, and brachial plexus were not reactive as well. However, the cervical sympathetic ganglion and portions of the immediately adjacent sympathetic trunk contained high concentrations of extracellular apo E along the surface of nerve fibers and along the endoneurium. Extracellular apo A-I was undetectable except for a very faint reaction in the arachnoid of the cerebrum.

\section{Discussion}

Immunoreactive apo $\mathrm{E}$ has been observed in large quantities in nervous tissue. In the central nervous system, apo $\mathrm{E}$ is present principally within astrocytic glia. Typical fibrous astrocytes of the white matter and protoplasmic astrocytes of the gray matter are immunoreactive for apo E. In addition, specialized astrocytic cells, namely, Bergmann glia of the cerebellum, tanycytes of the third ventricle, pituicytes, and Müller cells of the retina, are all rich in apo E. Oligodendroglia, neurons, cells of the choroid plexus, and cells at the dural surface of the arachnoid are negative for apo $\mathrm{E}$ immunoreactivity, as are most cells identified as microglia or ependymal cells. Within the peripheral nervous system, glial cells associated with neuron cell bodies (enteric glia and satellite cells) and nonmyelinating Schwann cells display apo E immunoreactivity; however, Schwann cells involved in myelination do not appear to be reactive for apo $\mathrm{E}$ (results summarized in Table I).

Apo A-I, another plasma protein similar to apo $E$ in size and found on many of the same lipoprotein particles in the plasma, can be detected by immunocytochemical techniques in very low levels within astrocytes only in those regions of the brain where plasma contamination is expected. Within the peripheral nervous system it could not be detected in glia at all. These findings, along with the observations that the apo $\mathrm{E}$ of the brain has a slightly higher apparent molecular weight than plasma apo E (Fig. 1) and that apo E mRNA is present in the brain (16), suggest that the apo $E$ identified in nervous tissue is not a plasma contaminant but a specific product of this tissue.

In the central nervous system, the coverings of the brain and the walls of blood vessels are separated from the nervous tissue by the basement membrane and foot processes of astrocytes. The presence of extracellular apo $E$ at these sites and of intracellular apo $\mathrm{E}$ along the entire length of most of the astrocytic cell processes that reach these surfaces suggests that apo $E$ is a secretory product of the astrocyte and that its secretion is directed toward the surfaces of nervous tissue where a basement membrane is found. This organization is most clearly demonstrated by the Müller cells of the retina. The tanycytes of the ventrolateral walls of the third ventricle would appear to be the only exception. Their secretion of apo $\mathrm{E}$ appears to be directed toward the ventricle itself. The presence of apo $\mathrm{E}$ in the Golgi apparatus and secretory vesicles of the Bergmann glial cells confirms the conclusion that apo $\mathrm{E}$ is a secretory product of the astrocyte. In addition, preliminary results from studies of primary cultures

times seen in processes of cells between the basement membranes (BM) of the nervous tissue and blood vessels. These processes are probably those of macrophages accompanying these vessels $(\times 21,000)$. 

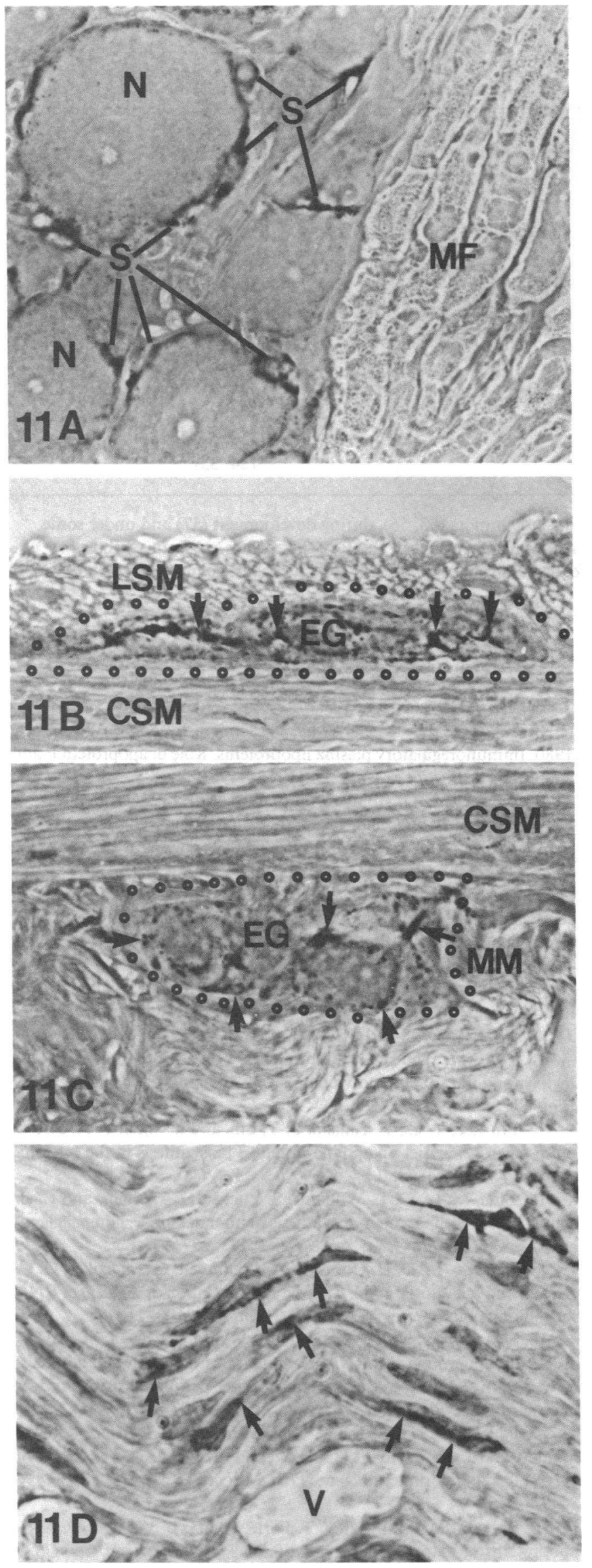

of rat brain cells show that cells identified as astrocytes produce apo $E$ in culture (58).

The uniform and unique presence of immunoreactive apo $E$ in astrocytes, specialized astrocytic cells, satellite cells, enteric glia, and nonmyelinating Schwann cells indicates that this apolipoprotein may be a valuable marker for the identification of these cell types. This uniform distribution is in contrast to the more variable expression of GFAP or GFAP-like proteins by these same cells. A summary of GFAP reactivity, as reported in the literature and as determined in the present study, is compiled in Table $\mathbf{I}$.

The precise role of apo $\mathrm{E}$ in neural tissue metabolism and the significance of its secretion by astrocytes and nonmyelinating peripheral glia is open to speculation. In the central nervous system, astrocytes are the cellular interface between the nervous tissue and the blood vessels or other surfaces of nonneural origin. Nonmyelinating peripheral glia (satellite cells, enteric glia, and certain Schwann cells) resemble astrocytes in that they too isolate nervous tissue by their cellular processes and basement membranes. In both the central and peripheral nervous systems, those cells that insulate neuronal processes or surfaces by forming myelin do not secrete apo E. Astrocytes function in part to support neuronal tissue through the maintenance of the extracellular milieu: they take up or release ions, small metabolites, and neurotransmitters and provide a skeletal framework, extracellular matrix, and other factors (for review, see reference 59). In addition, astrocytes may have an immunologic function. It has been reported that astrocytes in culture secrete lymphokine interleukin 1 (60) and express Ia antigen in response to gammainterferon (61). The astrocyte in culture has even been shown to present antigen to $T$ lymphocytes (62). The nonmyelinating peripheral nervous system glia may have support functions similar to those of the astrocyte.

Although the possible role of apo $\mathrm{E}$ in modulating any of these cell functions remains to be determined, it is reasonable to speculate that apo $\mathrm{E}$ functions in nervous tissue in much the same manner that it does in other tissues. The presence of apo E-containing lipoproteins in the cerebrospinal fluid (18) indicates that apo E could participate in the transport of lipids or lipidsoluble compounds into and out of the nervous system or in their redistribution among cells of the nervous system. Lipoprotein particles may also be active in the export of cholesterol from the brain to plasma (63), with lipoproteins that contain cholesterol leaving the brain along with the cerebrospinal fluid via the arachnoid granulations and deep lymphatics. At the present time, however, little is known about lipid movement within the cerebrospinal fluid or the interstitial fluid of tissue.

Figure 11. Phase-contrast micrographs of unstained $(A-C)$ and lightly stained $(D)$ sections of rat peripheral nervous tissue reacted for apo $\mathrm{E}$ (dark reaction product). $(A)$ In the dorsal root ganglion, nerve cells $(\mathrm{N})$ and Schwann cells among the myelinated fibers (MF) are not reactive, but the satellite cells $(S)$ immediately surrounding nerve cell bodies are reactive $(\times 555)$. ( $B)$ Cells in the enteric ganglia (EG) between the longitudinal (LSM) and circular (CSM) layers of smooth muscle are reactive (arrows) $(\times 590)$. (C) Cells in the enteric ganglia (EG) interior to the layer of circular smooth muscle (CSM) and near the muscularis mucosa (MM) are reactive (arrows) as well $(\times 790)$. $(D)$ Within the cervical portion of the sympathetic trunk, nonmyelinating Schwann cells show reactivity bordering their nuclei (arrows). Blood vessel (V) $(\times 980)$. 
Table I. Comparison of the Distribution of Apo E with GFAP in the Central Nervous System and GFAP-Cross-Reacting Protein in the Peripheral Nervous System

\begin{tabular}{|c|c|c|c|}
\hline \multirow[b]{2}{*}{ Cell type } & \multirow[b]{2}{*}{$\begin{array}{l}\text { Apo E } \\
\text { reactivity }\end{array}$} & \multicolumn{2}{|c|}{ GFAP reactivity } \\
\hline & & Present study & $\begin{array}{l}\text { Previous studies (literature } \\
\text { references) }\end{array}$ \\
\hline Protoplasmic & ++ & +- & $+-\ddagger(31-35)$ \\
\hline Fibrous astrocytes & ++ & ++ & $++(31-36)$ \\
\hline Bergmann glia & ++ & ++ & $++(31,34-36,44,45)$ \\
\hline Tanycytes & ++ & ND & $++(46)$ \\
\hline Pituicytes & ++ & ND & $++(47,48)$ \\
\hline Müller cells & ++ & ++ & $+-(35,49,55)$ \\
\hline Enteric glia & ++ & ++ & $++(50,51)$ \\
\hline Satellite cells & ++ & - & $+-(44,51)$ \\
\hline Nonmyelinating Schwann cells & + & - & $+-(35,44,51-53)$ \\
\hline Myelinating Schwann cells & - & - & $-(35,44,51,53)$ \\
\hline Oligodendrocytes & - & - & $-(34,35,44)$ \\
\hline Neurons & - & - & $-(34,35,44)$ \\
\hline Ependymal cells* & - & - & $-(33,34,35)$ \\
\hline Choroidal epithelium & - & - & $-(34,35)$ \\
\hline
\end{tabular}

* Ependymal cells are normally both GFAP and apo E-negative. However, in some tumors $(33,56)$, during development (57) and under some pathologic conditions (35), they may be GFAP-positive. Nothing is known about the expression of apo E in these states. $¥$ Both symbols (+-) together indicate that not all cells were positive in a given study or that different results were reported by various investigators. The symbols ++ indicte that a strong positive reaction was observed.

Novel functions for apo $\mathrm{E}$ within the nervous system must be considered, however, in future studies.

\section{Acknowledgments}

The excellent technical and photographic assistance of Emelia McFarland, Linda Anderson, Donna Foss, and James X. Warger is gratefully acknowledged. We wish to thank Sylvia Johnson and Michele Prator for manuscript preparation, Russell Levine, Barbara Allen, and Sally Gullatt Seehafer for editorial assistance, Guliano Sclano for his work on the electron microscopic immunocytochemistry, and Dr. Stephen DeArmand for his review of and comments concerning the slides. Rabbit anti-apo $E$ and anti-apo A-I serum were gifts from Drs. Thomas L. Innerarity and Karl H. Weisgraber. Rabbit anti-GFAP serum was a gift from Dr. L. F. Eng (Stanford University).

\section{References}

1. Mahley, R. W., and T. L. Innerarity. 1983. Lipoprotein receptors and cholesterol homeostasis. Biochim. Biophys. Acta. 737:197-222.

2. Mahley, R. W., T. L. Innerarity, S. C. Rall, Jr., and K. H. Weisgraber. 1984. Plasma lipoproteins: apolipoprotein structure and function. J. Lipid Res. 25:1277-1294.

3. Havel, R. J., J. L. Goldstein, and M. S. Brown. 1980. Lipoproteins and lipid transport. In Metabolic Control and Disease. P. K. Bondy and L. E. Rosenberg, editors. W. B. Saunders Co., Philadelphia. 393-494.

4. Hui, D. Y., T. L. Innerarity, and R. W. Mahley. 1981. Lipoprotein binding to canine hepatic membranes: metabolically distinct apo-E and apo-B,E receptors. J. Biol. Chem. 256:5646-5655.

5. Mahley, R. W., D. Y. Hui, T. L. Innerarity, and K. H. Weisgraber. 1981. Two independent lipoprotein receptors on hepatic membranes of dog, swine, and man. Apo-B,E and apo-E receptors. J. Clin. Invest. 68: 1197-1206.

6. Angelin, B., C. A. Raviola, T. L. Innerarity, and R. W. Mahley. 1983. Regulation of hepatic lipoprotein receptors in the dog. Rapid regulation of apolipoprotein B,E receptors, but not of apolipoprotein E receptors, by intestinal lipoproteins and bile acids. J. Clin. Invest. 71: 816-831.

7. Gordon, V., T. L. Innerarity, and R. W. Mahley. 1983. Formation of cholesterol- and apoprotein E-rich high density lipoproteins in vitro. J. Biol. Chem. 258:6202-6212.

8. Hui, D. Y., J. A. K. Harmony, T. L. Innerarity, and R. W. Mahley. 1980. Immunoregulatory plasma lipoproteins. Role of apoprotein $E$ and apoprotein B. J. Biol. Chem. 255:11775-11781.

9. Avila, E. M., G. Holdsworth, M. Sasaki, B. L. Jackson, and J. A. Harmony. 1982. Apoprotein E suppresses phytohemagglutinin-activated phospholipid turnover in peripheral blood mononuclear cells. J. Biol. Chem. 257:5900-5909.

10. Curtiss, L. K., D. H. DeHeer, and T. S. Edgington. 1977. In vivo suppression of the primary immune response by a species of low density serum lipoprotein. J. Immunol. 118:648-652.

11. Curtiss, L. K., and T. S. Edgington. 1979. Differential sensitivity of lymphocyte subpopulations to suppression by low density lipoprotein inhibitor, and immunoregulatory human serum low density lipoprotein. J. Clin. Invest. 63:193-201.

12. Wu, A.-L., and H. G. Windmueller. 1979. Relative contributions by liver and intestine to individual plasma apolipoproteins in the rat. $J$. Biol. Chem. 254:7316-7322.

13. Lin-Lee, Y.-C., Y. Tanaka, C.-T. Lin, and L. Chan. 1981. Effects of an atherogenic diet on apolipoprotein $\mathrm{E}$ biosynthesis in the rat. Biochemistry. 20:6474-6480.

14. Blue, M.-L., D. L. Williams, S. Zucker, S. A. Khan, and C. B. Blum. 1983. Apolipoprotein E synthesis in human kidney, adrenal gland, and liver. Proc. Natl. Acad. Sci. USA. 80:283-287.

15. Reue, K. L., D. H. Quon, K. A. O'Donnell, G. J. Dizikes, G. C. Fareed, and A. J. Lusis. 1984. Cloning and regulation of messenger RNA for mouse apolipoprotein E. J. Biol. Chem. 259:2100-2107.

16. Elshourbagy, N. A., W. S. Liao, R. W. Mahley, and J. M. Taylor. 1984. Apolipoprotein E mRNA is abundant in the brain and adrenals, as well as in the liver, and is present in other peripheral tissues of rats and marmosets. Proc. Natl. Acad. Sci. USA. 82:203-207.

17. Paik, Y.-K., D. J. Chang, C. A. Reardon, G. E. Davies, R. W. Mahley, and J. M. Taylor. 1985. Nucleotide sequence and structure of the human apolipoprotein E gene. Proc. Natl. Acad. Sci. USA. 82:34453449.

18. Roheim, P. S., M. Carey, T. Forte, and G. L. Vega. 1979. Apolipoproteins in human cerebrospinal fluid. Proc. Natl. Acad. Sci. USA. 76:4646-4649. 
19. Felgenhauer, D. 1974. Protein size and cerebrospinal fluid composition. Klin. Wochenschr. 52:1158-1164.

20. Basu, S. K., M. S. Brown, Y. K. Ho, R. J. Havel, and J. L. Goldstein. 1981. Mouse macrophages synthesize and secrete a protein resembling apolipoprotein E. Proc. Natl. Acad. Sci. USA. 78:7545-7549.

21. Basu, S. K., Y. K. Ho, M. S. Brown, D. W. Bilheimer, R. G. W. Anderson, and J. L. Goldstein. 1982. Biochemical and genetic studies of the apoprotein E secreted by mouse macrophages and human monocytes. J. Biol. Chem. 257:9788-9795.

22. Werb, Z., and J. R. Chin. 1983. Onset of apoprotein E secretion during differentiation of mouse bone marrow-derived mononuclear phagocytes. J. Cell Biol. 97:1113-1118.

23. Werb, Z., and J. R. Chin. 1983. Apoprotein E is synthesized and secreted by resident and thioglycollate-elicited macrophages but not by pyran copolymer- or bacillus calmette-guerin-activated macrophages. $J$. Exp. Med. 158:1272-1293.

24. Boyles, J., R. E. Pitas, and R. W. Mahley. 1984. Apolipoprotein E within astrocytes of the brain. Circulation. 70(Suppl. 2):20. (Abstr.)

25. Courtoy, P. J., and J. Boyles. 1983. Fibronectin in the microvasculature: localization in the pericyte-endothelial interstitium. $J$. $\mathrm{Ul}$ trastruct. Res. 83:258-273.

26. Laemmli, U. K. 1970. Cleavage of structural proteins during the assembly of the head of bacteriophage T4. Nature (Lond.). 227:680-685.

27. Towbin, H., T. Staehelin, and J. Gordon. 1979. Electrophoretic transfer of proteins from polyacrylamide gels to nitrocellulose sheets: procedure and some applications. Proc. Natl. Acad. Sci. USA. 76:43504354.

28. Weisgraber, K. H., and R. W. Mahley. 1983. Characterization of rat plasma lipoproteins. In CRC Handbook of Electrophoresis, Vol. IV: Lipoproteins of Non-human Species. L. A. Lewis and H. K. Naito, editors. CRC Press, Boca Raton, FL. 103-131.

29. Suissa, M. 1983. Spectrophotometric quantitation of silver grains eluted from autoradiograms. Anal. Biochem. 133:511-514.

30. Mahley, R. W., and K. S. Holcombe. 1977. Alterations of the plasma lipoproteins and apoproteins following cholesterol feeding in the rat. J. Lipid Res. 18:314-324.

31. Ludwin, S. K., J. C. Kosek, and L. F. Eng. 1976. The topographical distribution of S-100 and GFA proteins in the adult rat brain: an immunohistochemical study using horseradish peroxidase-labelled antibodies. J. Comp. Neurol. 165:197-208.

32. Bock, E. 1978. Nervous system specific proteins. J. Neurochem. 30:7-14.

33. Duffy, P. E., L. Graf, Y.-Y. Huang, and M. M. Rapport. 1979. Glial fibrillary acidic protein in ependymomas and other brain tumors. Distribution, diagnostic criteria, and relation to formation of processes. J. Neurol. Sci. 40:133-146.

34. Bignami, A., and D. Dahl. 1974. Astrocyte-specific protein and neuroglial differentiation. An immunofluorescence study with antibodies to the glia fibrillary acidic protein. J. Comp. Neurol. 153:27-38.

35. Eng, L. F., and S. J. DeArmond. 1983. Immunochemistry of the glial fibrillary acidic protein. Prog. Neuropathol. 5:19-39.

36. Bignami, A., L. F. Eng, D. Dahl, and C. T. Uyeda. 1972. Localization of the glial fibrillary acidic protein in astrocytes by immunofluorescence. Brain Res. 43:429-435.

37. Peters, A., S. L. Palay, and H. Webster. 1976. The Fine Structure of the Nervous System: The Neurons and Supporting Cells. W. B. Saunders Co., Philadelphia

38. Shantha, T. R., and G. H. Bourne. 1968. The perineural epithelium-a new concept. In The Structure and Function of Nervous Tissue. Vol. 1. G. H. Bourne, editor. Academic Press, Inc., New York. 379459.

39. Polyak, S. L. 1941. The Retina. The University of Chicago Press, Chicago, IL.

40. Woltor, J. R. 1959. Glia of the human retina. Am. J. Ophthalmol. 48:370-393.

41. Bleier, R. 1971. The relations of ependyma to neurons and cap- illaries in the hypothalamus: Golgi-Cox study. J. Comp. Neurol. 142: 439-464.

42. Palay, S. L., and V. Chan-Palay. 1974. Cerebellar Cortex. SpringerVerlag, New York.

43. Millhouse, O. E. 1974. A Golgi study of third ventricle tanycytes in the adult rodent brain. Z. Zellforsch. 121:1-13.

44. Yen, S.-H., and K. L. Fields. 1981. Antibodies to neurofilament, glial filament, and fibroblast intermediate filament proteins bind to different cell types of the nervous system. J. Cell Biol. 88:115-126.

45. Schachner, M., E. T. Hedley-Whyte, D. W. Hsu, G. Schoonmaker, and A. Bignami. 1977. Ultrastructural localization of glial fibrillary acidic protein in mouse cerebellum by immunoperoxidase labeling. $\mathrm{J}$. Cell Biol. 75:67-73.

46. Bascó, E., P. L. Woodhams, F. Hajós, and R. Balázs. 1981. Immunocytochemical demonstration of glial fibrillary acidic protein in mouse tanycytes. Anat. Embryol. 162:217-222.

47. Suess, U., and V. Pliska. 1981. Identification of the pituicytes as astroglial cells by indirect immunofluorescence-staining for the glial fibrillary acidic protein. Brain Res. 221:27-33.

48. Salm, A. K., G. I. Hatton, and G. Nilaver. 1982. Immunoreactive glial fibrillary acidic protein in pituicytes of the rat neurohypophysis. Brain Res. 236:471-476.

49. Bignami, A., and D. Dahl. 1979. The radial glia of Müller in the rat retina and their response to injury. An immunofluorescence study with antibodies to the glia fibrillary acidic (GFA) protein. Exp. Eye Res. 28:63-69.

50. Jessen, K. R., and R. Mirsky. 1980. Glia cells in the enteric nervous system contain glial fibrillary acidic protein. Nature (Lond.). 286:736-737.

51. Jessen, K. R., R. Thorpe, and R. Mirsky. 1984. Molecular identity, distribution and heterogeneity of glial fibrillary acidic protein: an immunoblotting and immunohistochemical study of Schwann cells, satellite cells, enteric glia and astrocytes. J. Neurocytol. 13:187-200.

52. Barber, P. C., and R. M. Lindsay. 1982. Schwann cells of the olfactory nerves contain glial fibrillary acidic protein and resemble astrocytes. Neuroscience. 7:3077-3090.

53. Dahl, D., N. H. Chi, L. E. Miles, B. T. Nguyen, and A. Bignami. 1982. Glial fibrillary acidic (GFA) protein in Schwann cells: fact or artifact? J. Histochem. Cytochem. 30:912-918.

54. Bignami, A., and D. Dahl. 1977. Specificity of glial fibrillary acidic protein for astroglia. J. Histochem. Cytochem. 25:466-469.

55. Shaw, G., and K. Weber. 1983. The structure and development of rat retina: an immunofluorescence microscopical study using antibodies specific for intermediate filament proteins. Eur. J. Cell. Biol. 30:219232.

56. Deck, J. H. N., L. F. Eng, J. Bigbee, and S. M. Woodcock. 1978. The role of glial fibrillary acidic protein in the diagnosis of central nervous system tumors. Acta Neuropathol. 42:183-190.

57. Roessmann, U., M. E. Velasco, S. D. Sindely, and P. Gambetti. 1980. Glial fibrillary acidic protein (GFAP) in ependymal cells during development. An immunologic study. Brain Res. 200:13-21.

58. Pitas, R. E., S. Lee, J. K. Boyles, and R. W. Mahley. 1985. Brain cells in culture secrete apo-E and metabolize apo-E-containing lipoproteins. Fed. Proc. 44:754. (Abstr.)

59. Walicke, P. A. 1982. Maintenance state of the art report. In Neuronal-Glial Cell Interrelationships. T. A. Sears, editor. SpringerVerlag, Berlin. 169-202.

60. Fontana, A. 1982. Astrocytes and lymphocytes: intercellular communication by growth factors. J. Neurosci. Res. 8:443-451.

61. Hirsch, M.-R., J. Wietzerbin, M. Pierres, and C. Gordis. 1983. Expression of Ia antigens by cultured astrocytes treated with gammainterferon. Neurosci. Lett. 41:199-204.

62. Fontana, A., W. Fierz, and H. Wekerle. 1984. Astrocytes present myelin basic protein to encephalitogenic T-cell lines. Nature (Lond.). 307:273-276.

63. Serougne, C., C. Lefevre, and F. Chevallier. 1976. Cholesterol transfer between brain and plasma in the rat: a model for the turnover of cereberal cholesterol. Exp. Neurol. 51:229-240. 